\title{
$\mathrm{L}$ 형 아이리스와 투과 공진 개구를 이용한 소형화된 도파관 여파기 설계 및 실험
}

\section{Design and Experiment of a Miniaturized Waveguide Band-Pass Filter Using L-Type Inverter and Small Resonant Aperture}

\author{
최 진 영·김 병 문 ${ }^{\star}$. 조 영 기 \\ Jinyoung Choi $\cdot$ Byung-Mun Kim* · Young-Ki Cho \\ 요 약 \\ 본 논문에서는 도파관의 단면(waveguide transverse plane)에 아이리스(iris)를 갖는 구조들을 도파관의 진행 방
} 향으로 일정한 간격으로 배치하여 소형의 대역 통과 여파기를 구현하는 방법을 제시하고자 한다. 이를 위하여 리지가 장하된 원형 개구 아이리스를 여파기 설계의 기본 공진기 구조로 활용하며, 임피던스 인버터(impedance inverter)로 동작하게 되는 L형 아이리스를 새롭게 제안하여 여파기의 길이 방향 크기를 줄이는데 사용하였다. 최종 제작된 여파기는 중심 주파수 $10 \mathrm{GHz}$ 에서 $400 \mathrm{MHz}$ 의 대역폭을 갖는데, 기존의 여파기 설계 방식에 비하 여 $70 \%$ 의 소형화를 달성하였다.

\section{Abstract}

In this paper, a miniaturized band-pass filter structure, which comprises the irises of small resonant aperture and L-type irises inverter, is proposed. Ridged circular aperture iris is chosen as an elementary resonator. L-type iris which is placed between two adjacent elementary resonators is newly proposed as impedance inverter in order to reduce longitudinal length of the proposed filter. The fabricated minimized filter has $400 \mathrm{MHz}$ bandwidth at the $10 \mathrm{GHz}$ center frequency and the whole size is reduced to $70 \%$ in length compared to conventional filter.

Key words : Waveguide Band-Pass Filter, Transmission Resonant Aperture, L-Type Iris, Compact Filter

\section{I. 서 론}

최근에 초고주파 대역에서 도파관을 이용한 여파 기 설계 분야에서는 여파기 설계와 직접적인 관련성 이 없어 보이는 FSS(Frequency Selective Surface) 분야 혹은 메타 물질(meta-material) 분야의 기본 소자(unit element)를 여파기의 기본 공진기(elementary resona- tor) 구조로 활용하고 있다.

먼저 FSS 구조의 기본요소(unit cell)를 도파관의 내부에 배치하여 여파기 특성을 얻은 연구 ${ }^{[1],[2]}$ 에서 는 최적화 알고리즘으로 알려진 $\mathrm{GA}($ Genetic Algori$\mathrm{thm}$ )를 사용하여 원하는 주파수 특성을 갖는 기본 공진기를 찾고, 이를 여파기 설계에 반영하였다. 그 러나 이러한 방식은 수치 계산이 복잡한 $\mathrm{GA}$ 를 사용

\footnotetext{
「이 논문은 경북대학교 2단계 두뇌한국 21사업에 의하여 지원되었으며, 2011년도 정부(교육과학기술부)의 재원으로 한국연구재단 의 지원을 받아 수행된 기초연구사업임(2011-15950000).」

경북대학교 전자공학부(School of Electronics Engineering, IT College, Kyungpook University)

*경북도립대학교 IT특약 계열(Division of IT Cooperative Systems, Gyeongbuk Provincial College)

- Manuscript received December 26, 2011 ; Revised February 6, 2012 ; Accepted February 27, 2012. (ID No. 20111226-167)

- Corresponding Author : Young-Ki Cho (e-mail : ykcho@ee.knu.ac.kr)
} 
해야 하는 번거로움과 최적화된 공진기의 물리적인 동작 특성을 파악하기 어렵기 때문에 체계적인 여파 기 설계 방식의 정립이 어렵다.

다음으로 메타 물질 분야에서 기본 소자로서 널 리 알려진 CSRR(Complementary Split Ring Resonator) 구조를 도파관의 내부에 배치하여 여파기 특성을 얻 은 연구 ${ }^{[3][[4]}$ 에서는 개구 형태의 인버터(inverter) 구조 를 도입하여 여파기를 소형화할 수 있는 방법을 제 시하였다. 그러나 기본 공진기로 사용된 CSRR 구조 가 여파기의 기본 공진기로 동작하기 위한 투과 공 진(transmission resonance) 특성에 관한 충분한 논의 ${ }^{[5]}$ 가 이루어지지 않았다. 또한, 개구 형태의 인버터 구 조가 C형(capacitive type)이 되어야 하는지 L형(inductive type)이 되어야 하는지에 대한 논의 즉, 전체 여파기 구조의 물리적인 동작 특성에 관한 논의가 부족하였다.

본 논문에서는 소형 안테나 구조 및 근접장 현미 경의 탐침(near-field microscope probe) 구조하,[7] 설계 에 활용하기 위한 목적으로 연구되어 온 투과 공진 개구 ${ }^{[8] \sim[10]}$ 의 한 형태인 리지가 장하된 소형 원형 개 구 $^{[11] \sim[13]}$ 를 여파기의 기본 공진기 구조로 새롭게 제 안하였다. 또한, 인버터 구조로서 기존의 $\lambda / 4$ 변환 기( $\lambda / 4$ transformer $)$ 대신에 $\mathrm{L}$ 형 아이리스를 도입하 여 여파기를 도파관의 길이 방향으로 소형화하는 방 법을 제시하였다. 이러한 두 소자를 결합하여 기존 의 설계방식으로 제작한 여파기와 비교하여 동일한 성능을 유지하면서 체적이 대략 $70 \%$ 소형화된 여 파기를 구현하였다.

\section{II. 본 론}

\section{2-1 여파기 구조}

그림 1 은 제안된 여파기의 구조와 구성 소자를 도 시한 것이다. 여파기는 WR-90 표준형 도파관 내부 에 총 3 개의 평면형(planar type) 구조물을 $1.43 \mathrm{~mm}$ 의 동일한 간격으로 배치하여 구성한다. 각 구조물은 그림 1(b)에 도시된 것처럼 비유전율 $\epsilon_{r}=2.55$, 두께 $0.3 \mathrm{~mm}$ 인 Taconic TLX-9 마이크로스트립(micro-stripe) 기판으로 제작되는데, 먼저 기판을 도파관의 플랜지(flange) 면과 동일한 형상으로 잘라낸 이후에
(2) L-type iris

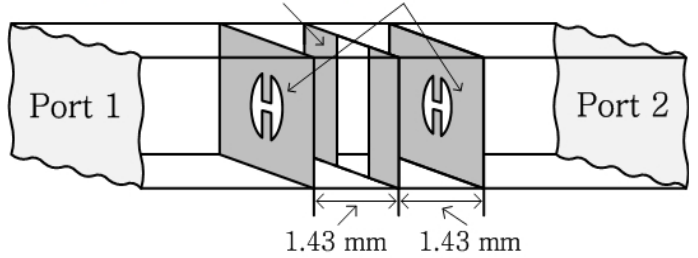

(a) 입체도

(a) Solid view

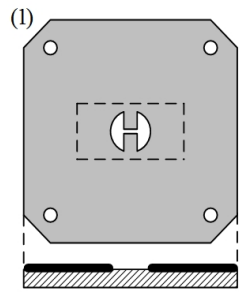

Ridged circular aperture

(b) 제안된 여파기의 구성 소자

(b) Elements of proposed filter

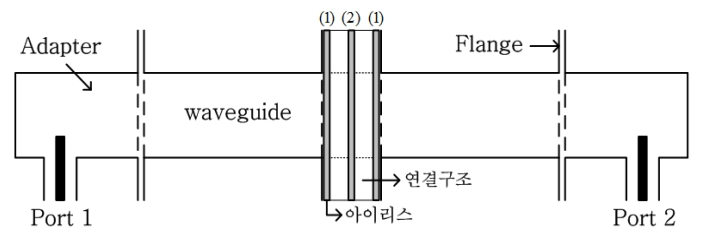

(c) 실험 구성도

(c) Experimental setup

그림 1. 제안된 여파기의 구성도

Fig. 1. Geometry of proposed filter.

접지(ground)면을 없애고 나머지 도체면에 적절한 개구 형상을 식각(etching)하여 제작된다. 이웃하는 구조물 사이에는 $1.43 \mathrm{~mm}$ 두께를 갖는 스테인리스 (stainless steel) 재질의 연결 구조를 삽입하여 각 구 조물을 연결하였다.

그림 1(b)에 표시된 (1)은 리지가 장하된 소형 원 형 개구 아이리스(small ridged circular aperture iris)이 며, (2)는 L형 아이리스(L-type iris)이다. 2-2절부터는 두 아이리스가 도파관의 횡단면에 위치한 경우, $\mathrm{EM}$ $\mathrm{S} / \mathrm{W}$ tool(HFSS)을 이용하여 각각의 주파수 응답 특 성을 조사하고, 그 동작 원리를 살펴볼 것이다.

2-2 여파기의 첫 번째 구성 소자로서의 리지 가 장하된 소형 원형 개구 아이리스 


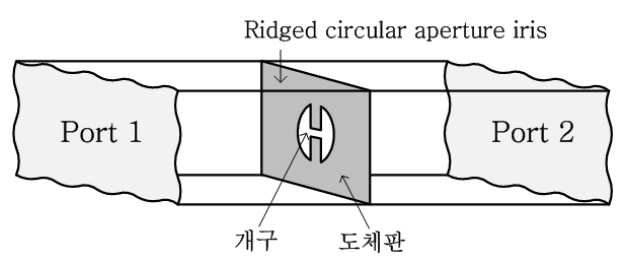

(a) 입체도

(a) Solid view

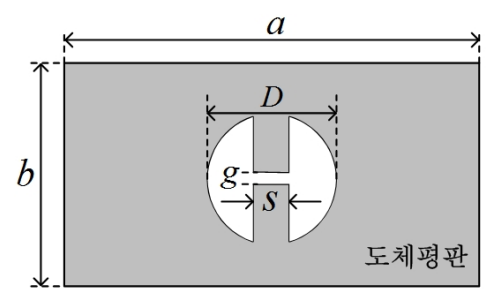

(b) 정면도

(b) Front view

그림 2. 리지가 장하된 원형 개구 아이리스

Fig. 2. Geometry of ridged circular aperture iris.

참고문헌 [8]의 연구에서는 전자파의 투과 전력이 매우 낮은 것으로 알려진 소형의 사각 개구를 유도 성분(inductive)으로 해석하여 개구의 중앙에 $\mathrm{C}(\mathrm{ca}-$ pacitor)를 추가하여 개구를 공진시킴으로써 소형 개 구의 낮은 투과 전력을 향상시키는 방법을 제시하였 다. 본 연구에서는 그림 2에 도시된 것처럼 소형 원 형 개구의 중앙에 C성분(capacitive)을 갖도록 리지 구조를 장하한 투과 공진 개구를 여파기 설계의 기 본 공진기 구조로 새롭게 활용하였다.

그림 2는 그 구조를 간단히 도시하고 있다. 즉, 도 파관의 횡단면을 두께가 $0.035 \mathrm{~mm}$ 인 도체 평판으로 막고, 그 중앙에 리지가 장하된 원형 개구를 위치시 킨 구조이다. 이러한 개구 결합(aperture coupling) 구 조를 본 연구에서는 리지가 장하된 소형 원형 개구 아이리스로 명명하였다.

이러한 개구 형태의 기본 공진기가 갖는 주파수 응답 특성을 살펴보기 위하여 그림 2(b)에 표시된 파 라미터의 치수를 $a=22.86, b=10.16, D=6.9, s=1.9, g=$ 0.4 (단위 : mm)로 정하고, $\mathrm{EM} \mathrm{S} / \mathrm{W}$ tool(HFSS)을 이용 하여 반사 계수 $\left(S_{11}\right)$ 와 투과 계수 $\left(S_{21}\right)$ 를 그림 3에 점선 으로 나타내었다. 또한, 모의실험 결과의 타당성을 검증하기 위하여 그림 2(b)의 구조를 그림 $1(\mathrm{~b})(1)$ 의 아이리스 구조로 제작하여 그림 1(c)의 실험을 수행 하고, 그 결과를 그림 3에 실선으로 나타내었다. 두

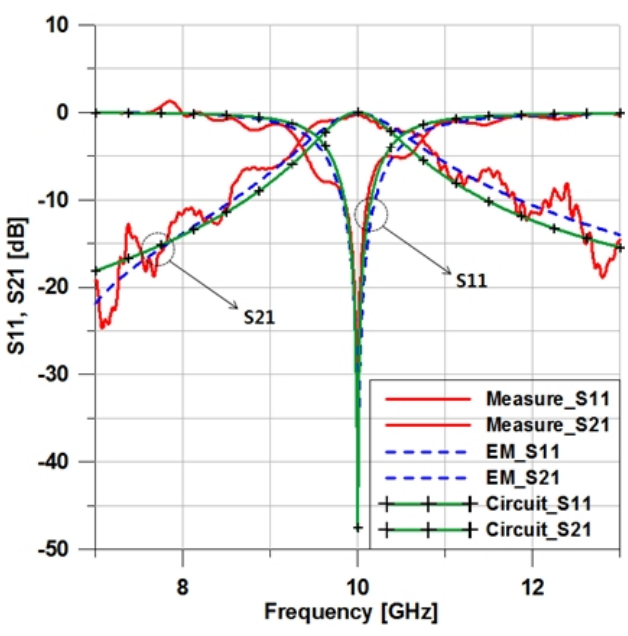

그림 3. 주파수 응답 특성

Fig. 3. Frequency response characteristics.

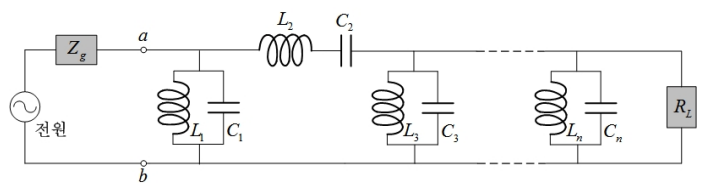

(a) 직렬 및 병렬 공진기로 구성된 여파기

(a) Band-pass filter using series and parallel resonators

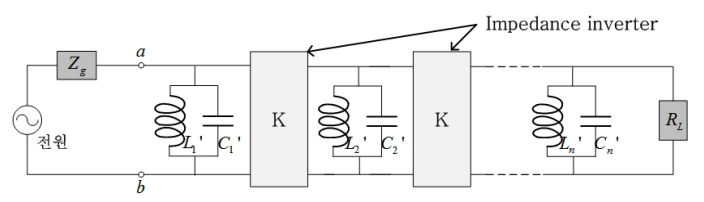

(b) 병렬 공진기로만 구성된 여파기

(b) Band-pass filter using only parallel resonators

그림 4. 대역 통과 여파기 회로

Fig. 4. Band-pass filter circuit.

결과 그래프가 서로 잘 일치하고, $10 \mathrm{GHz}$ 에서 통과 주파수가 나타남을 볼 수 있다. 이를 통하여 개구 아 이리스가 $\mathrm{L}, \mathrm{C}$ 공진 회로와 동일한 주파수 선택성을 갖는다는 점을 알 수 있다.

한편, 일반적인 여파기 설계에서는 그림 4(a)에 도 시된 것처럼 집중 소자(lumped element)인 L, C로 구 성된 직렬 공진기와 병렬 공진기를 번갈아 배치하여 원하는 필터링(filtering) 특성을 얻는다. 그러나 초고 주파 대역에서는 집중소자의 사용이 제한적이고, 각 각의 공진기를 근접시킨 경우에 강한 결합 현상이 발생하기 때문에, 이러한 구성 대신에 L, C 공진 회 로와 동일한 주파수 선택성을 갖는 구조 즉, 본 연구 
에서 제안한 리지가 장하된 원형 개구 아이리스와 같은 구조를 그림 4(b)에 도시된 것처럼 인버터(inverter) 구조로 연결함으로써 그림 4(a)와 동일한 특 성을 갖도록 한다. 이때 구현하고자 하는 여파기의 주파수 선택 특성(중심주파수, 대역폭, 스커트 특성, 군지연)을 조절하기 위해서는 기본 공진기가 갖는 $\mathrm{L}, \mathrm{C}$ 값 즉, 그림 $4(\mathrm{~b})$ 의 각 단에 위치한 $L_{n}{ }^{\prime}, C_{n}{ }^{\prime}$ 값을 원하는 설계 사양에 맞도록 변경할 수 있어야 한다.

그림 5는 그림 2(b)에 도시된 리지가 장하된 원형 개구 아이리스의 직경 $D$ 와 리지 간격 $g$ 의 치수 변화 시에 따른 공진 주파수의 변화를 $\mathrm{EM} \mathrm{S} / \mathrm{W}$ tool(HF$\mathrm{SS})$ 로 모의 실험한 것이다. 그림 5(a)에서는 직경 $D$ 가 증가함에 따라 개구의 인덕턴스 성분이 증가함으

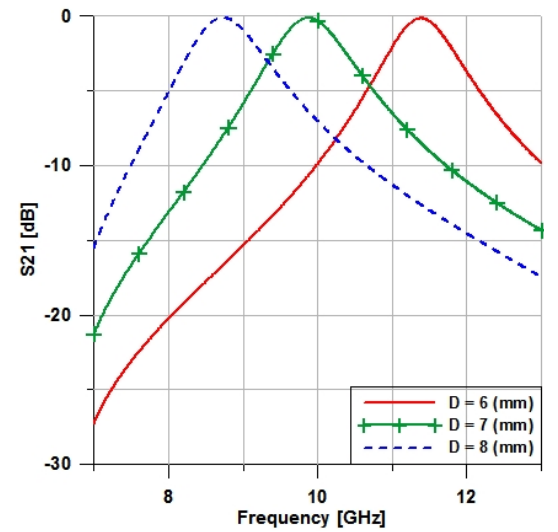

(a) 파라미터 $D$ 의 변화에 따른 주파수 특성

(a) Frequency characteristics versus diameter

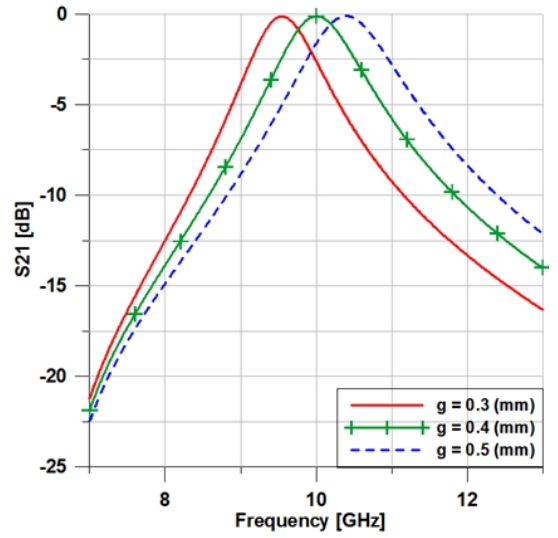

(b) 파라미터 $g$ 의 변화에 따른 주파수 특성

(b) Frequency characteristics versus ridge gap

그림 5. 구조 변경에 따른 공진 특성 변화

Fig. 5. Resonant characteristics versus geometry.
로써 공진 주파수가 낮아짐을 확인할 수 있다. 또한, 그림 5(b)에서는 리지 간격 $g$ 가 증가함에 따라 개구 의 커패시턴스 성분이 감소함으로써 공진 주파수가 높아짐을 확인할 수 있다.

이와 같이 개구 아이리스의 치수를 변경함에 따 라 얻은 투과 계수 $\left(S_{21}\right)$ 곡선으로부터 중심주파수와 반전력 대역폭(half power bandwidth)을 확인하여 Q (Quality factor)를 구하고, 결국 $\mathrm{L}, \mathrm{C}$ 값을 실험적으로 계산할 수 있다. 이러한 과정을 통하여 얻은 기본 공 진기를 그림 4(b)의 회로에 적용함으로써 원하는 주 파수 선택성을 갖는 여파기를 체계적으로 설계할 수 있다.

그림 2(b)에 도시된 구조의 치수를 $a=22.86, b=$ $10.16, D=6.9, s=1.9, \mathrm{~g}=0.4$ (단위 : $\mathrm{mm}$ )로 정하고 실험 한 결과로부터 그림 3의 투과 계수 $\left(S_{21}\right)$ 곡선을 얻을 수 있었는데, 전술한 방법을 이용하여 계산해 보면 그 $L, C$ 값이 대략 $L=0.0442 \mathrm{nH}, C=5.73 \mathrm{pF}$ 이다. 이를 Circuit $\mathrm{S} / \mathrm{W}$ tool(Ansoft designer)을 이용하여 모의실 험하고, 그 결과를 그림 3 에 (+) 표시가 있는 실선으 로 나타내었다. 이 결과는 $\mathrm{EM}$ 모의실험 결과 및 실 제 제작 실험 결과와 잘 일치함을 확인할 수 있다.

\section{2-3 여파기의 두 번째 구성 소자로서 L-Type In- verter 아이리스}

본 연구에서 제안한 투과 공진 개구를 이용한 평 판 형태(planar type)의 아이리스 구조는 자체적으로 주파수 선택성을 갖는다. 따라서 그 자체만으로도 대역 통과 여파기로의 사용이 가능하다. 그러나 다 양한 전기적인 시스템이 요구하는 설계 사양(중심 주파수, 대역폭, 스커트 특성, 군지연 특성)을 만족시 키기 위해서는 이러한 기본 공진기를 다단(multistage)으로 구성하여 설계하는 여파기 합성 과정이 필요하다.

기존에는 그림 4(b)의 impedance inverter $(K)$ 자리 에 $\lambda / 4$ 변환기를 사용하여 그림 4(a)와 동일한 특성 을 갖는 여파기를 구현하였다 ${ }^{[15],[16]}$. 그러나 $\lambda / 4$ 변 환기는 입력 신호의 $1 / 4$ 배 파장 $(\lambda)$ 길이를 갖는 전 송 선로에 해당하므로, 다단으로의 합성 과정에서 여파기의 길이 방향 크기가 동작주파수에 의존하게 된다. 따라서 여파기를 소형화하는 데 한계점을 지닌 


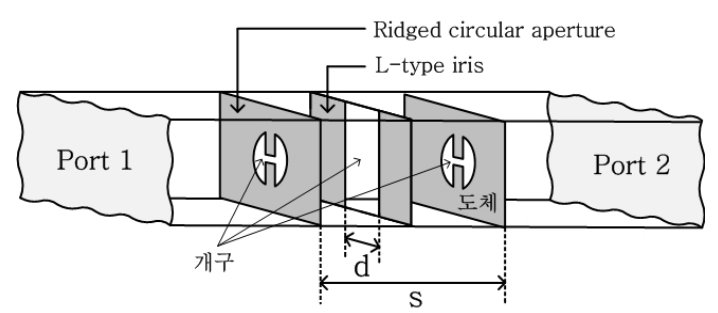

(a) 입체도

(a) Solid view

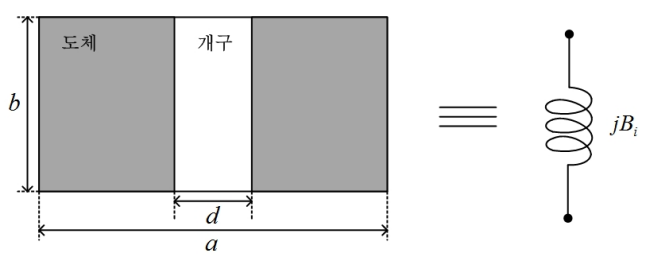

(b) 정면도

(b) Front view

그림 6. L형 아이리스 구조

Fig. 6. Geometry of L-type iris.

다. 본 연구에서는 기존의 $\lambda / 4$ 변환기 대신에 $\mathrm{L}$ 형 아이리스를 갖는 개구 형태의 새로운 인버터 구조를 도입하여 여파기의 길이 방향 크기를 소형화하는 방 법을 소개하고자 한다.

그림 6은 $\mathrm{L}$ 형 아이리스의 구조를 도시한 것이다. 즉, 도파관의 횡단면을 두께가 $0.035 \mathrm{~mm}$ 인 도체 평 판으로 막고, 중앙에 폭이 $d$ 인 슬롯을 세로 방향으 로 낸 구조이다. L형 아이리스가 이와 같이 도파관 의 내부에 위치하게 되면 슬릿 가장 자리 부분에 해 당하는 불연속 구조에 의하여 고차 모드가 발생하 고, 슬릿 근처에 자기적인 에너지가 축적된다. 따라 서 $\mathrm{L}$ 형 아이리스 구조는 식 $(1)^{[14]}$ 의 $B_{i}$ 에 해당하는 서셉턴스(susceptance) 성분을 갖는다. 식 (1)에 나타 난 $Y_{10}$ 은 도파관에서 발생하는 $\mathrm{TE}_{10}$ 모드의 특성 어 드미턴스(characteristic impedance)이고, $\lambda_{g}$ 는 동작 주 파수의 관내 파장(guided wavelength)이다.

$$
b_{i}=\frac{B_{i}}{Y_{10}}=-\frac{\lambda_{g}}{a} \cot ^{2}\left(\frac{\pi d}{2 a}\right)
$$

식 (1)을 살펴보면 $B_{i}$ 는 항상 음수이기 때문에 $\mathrm{L}$ 형 아이리스는 유도 성분(inductive component)으로 동작함을 알 수 있다. 그림 $6(\mathrm{~b})$ 에 도시된 슬롯 폭 $(d)$ 은 $0 \leq d \leq a$ 범위를 갖는데, 식(6)의 코탄젠트 함수 를 그래프로 그려보면 $d$ 가 감소할수록 $b_{i}$ 가 증가하

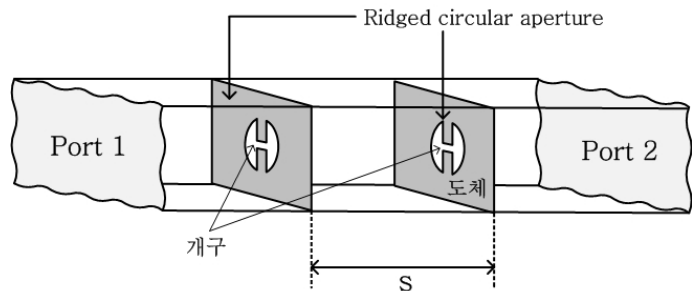

그림 7. 기존의 $\lambda / 4$ 임피던스 변환기를 이용하여 2 단 여파기를 구현한 방법

Fig. 7. Conventional method for two stage band-pass filter by using $\lambda / 4$ impedance transformer.

는 것을 확인할 수 있다. 따라서 $j Y_{10} b_{i}=j \omega L$ 이므 로 $d$ 가 감소할수록 $\mathrm{L}$ 형 아이리스의 유도 성분이 증 가함을 알 수 있다. 이러한 전기적인 특성을 갖는 $\mathrm{L}$ 형 아이리스가 그림 6(a)에 도시된 것처럼 이웃하는 2 개의 투과 공진 개구 사이에 위치한 경우에 전체 구조가 어떤 주파수 응답 특성을 갖는지 살펴보고자 한다.

그림 7은 L형 아이리스 없이 기본 공진기를 $S$ 만 큼 떨어뜨린 구조이다. 기존에는 기본 공진기를 연 결하여 여파기를 합성할 때의 인버터 구조로서, $S$ 를 $\lambda / 4$ 로 설정하는 $\lambda / 4$ 변환기를 사용하였다. 그런데, 이렇게 구성되는 여파기를 소형화하기 위하여 $S$ 를 줄인다면 어떤 현상이 발생하겠는가?

이를 조사하기 위하여 그림 7의 구조에서 $S$ 를 가 변해 보고, 그에 따른 주파수 응답 특성의 변화를 $\mathrm{EM}$ $\mathrm{S} / \mathrm{W}$ tool(HFSS)로 모의실험 하였다. 그림 $8(\mathrm{a})$ 는 반 사계수 $\left(S_{11}\right)$ 를 나타내었고, 그림 8(b)는 투과 계수 $\left(S_{21}\right)$ 를 나타내었다. 이때 리지가 장하된 소형 원형 개구 아이리스는 $10 \mathrm{GHz}$ 에서 공진하도록 $D=6.9, s=1.9$, $g=0.4$ (단위 : $\mathrm{mm}$ )로 설정하였고, $10 \mathrm{GHz}$ 에서 도파관 의 관내 파장 $(\lambda)$ 은 약 $40 \mathrm{~mm}$ 이다.

모의실험 결과, 두 가지 사실을 관찰할 수 있다. 첫째, 두 개구를 근접시킨 경우에 $f_{0}=10 \mathrm{GHz}$ 이던 공진 주파수가 $f_{L}$ 과 $f_{H}$ 로 분리된다. 둘째, 개구간 간격 $(S)$ 이 작을수록 $f_{L}$ 과 $f_{H}$ 의 간격이 더 커진다. 즉, $S=9.61 \mathrm{~mm}(\cong \lambda / 4)$ 인 경우에 그림 $8(\mathrm{~b})$ 그래프 상에서 $f_{L}$ 과 $f_{H}$ 의 간격이 적절히 유지되어 통과 대 역 전 영역에서 입력 신호가 감쇠없이 전달된다. 그 러나 여파기를 소형화하기 위하여 두 개구를 $S=6.61$ $\mathrm{mm}, S=3.61 \mathrm{~mm}$ 로 더 근접시키면 $f_{L}$ 과 $f_{H}$ 의 간격이 


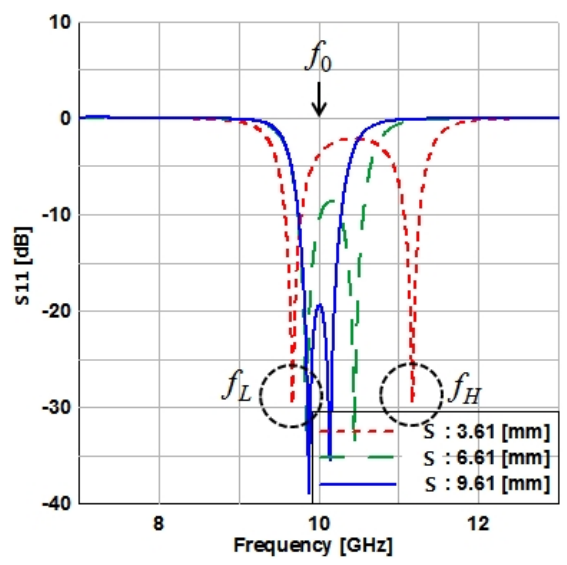

(a) 반사 계수

(a) Reflection coefficient

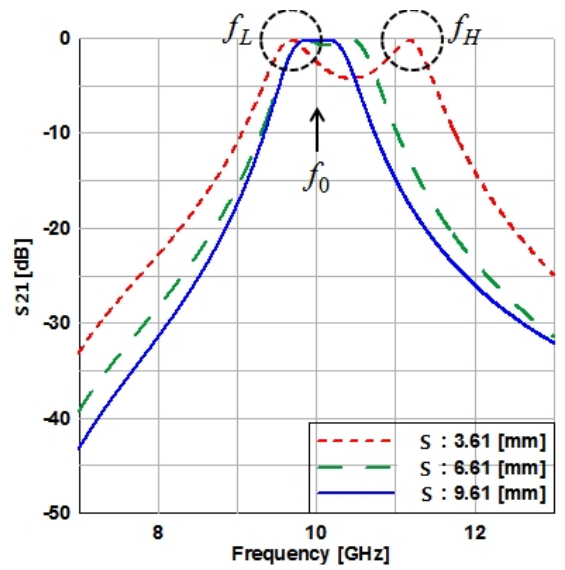

(b) 투과 계수

(b) Transmission coefficient

그림 8. 간격 $S$ 변화에 따른 주파수 응답 특성

Fig. 8. Frequency response versus parameter $S$.

커져서 통과 대역 중앙부의 리플(ripple) 진폭이 커지 게 되고, 결국 입력 신호의 전달 특성이 나빠진다.

$f_{H}$ 는 리지가 장하된 소형 원형 개구 아이리스 2 개와 도파관 벽에 의해 형성된 캐비티(cavity)의 공진 모드 주파수에 해당한다. $f_{H}$ 는 두 개구의 간격 $(S)$ 변 화에 민감한데, 간격 $(S)$ 이 작을수록 높아진다. $f_{L}$ 은 리지가 장하된 소형 원형 개구에 의한 공진 주파수 이며, 개구가 공진할 때 개구 중앙에 있는 리지 구조 에 강한 전계가 생성되기 때문에, 두 개구의 간격 $(S)$ 변화와 같은 외부 요인의 변화에 둔감하다.

이상의 실험 결과를 통하여 여파기를 소형화하고 자 두 개구 아이리스의 간격 $(S)$ 를 줄이면 $f_{L}$ 과 $f_{H}$ 의
간격이 벌어져 정상적인 통과 대역이 형성될 수 없 다. 즉, $\lambda / 4$ 변환기를 인버터(inverter) 구조로 활용한 기존 설계 방식으로는 여파기를 길이 방향으로 소형 화하는데 한계점이 있다. 이를 극복하고자 본 연구 에서는 그림 6(b)에 도시된 L형 아이리스를 그림 6(a)과 같이 두 투과 공진 개구 사이에 배치하고, 기 본 공진기로 사용된 투과 공진 개구 아이리스 간의 간격 $(S)$ 을 기존의 $9.61 \mathrm{~mm}$ 에서 $2.86 \mathrm{~mm}$ 로 줄였다. 그 결과로서 정상적인 대역 통과 특성을 갖는 소형 화된 여파기를 구현하였다. 이제부터 그 과정을 살 펴보자.

먼저 그림 6(a) 구조에서 $S=2.86 \mathrm{~mm}$ 로 고정하고, L형 아이리스의 슬릿 폭을 $d=1.5 \mathrm{~mm}, d=2.2 \mathrm{~mm}, d=$ $3.5 \mathrm{~mm}$ 로 조정하면서 반사특성 $\left(S_{11}\right)$ 및 투과 특성 $\left(S_{21}\right)$ 변화를 $\mathrm{EM} \mathrm{S} / \mathrm{W}$ tool(HFSS)로 모의실험하고, 그 결과를 그림 9에 나타내었다. 이때 여파기의 전체 길이에 해당하는 $S=2.86 \mathrm{~mm}$ 은 $10 \mathrm{GHz}$ 를 기준으로 관내 파장 $\left(\lambda_{g}=40 \mathrm{~mm}\right)$ 의 $1 / 14$ 배이다.

두 투과 공진 개구를 근접시켜 놓고, 그 사이에 삽입한 $\mathrm{L}$ 형 아이리스의 슬롯 폭 $(d)$ 을 점점 줄이면 그림 $9(\mathrm{a})$ 와 같이 $f_{H}$ 는 거의 변화가 없고, $f_{L}$ 은 점차 적으로 $f_{H}$ 쪽으로 이동한다. $f_{H}$ 가 $d$ 의 변화에 둔감 한 것은 $\mathrm{L}$ 형 아이리스가 삽입되었다고 하더라도 두 투과 공진 개구 아이리스와 도파관 벽이 형성한 캐 비티(cavity)의 크기는 고정되어 있기 때문에, 그 공 진 모드에 의해 발생된 $f_{H}$ 도 고정되기 때문이다. 반 면에 $f_{L}$ 은 $\mathrm{L}$ 형 아이리스가 갖는 유도 성분이 리지가 장하된 원형 개구 자체의 유도 성분에 영향을 주기 때문에 $d$ 가 감소할수록 $f_{L}$ 은 민감하게 증가한다.

그림 $9(\mathrm{~b})$ 를 살펴보면 $d=3.5 \mathrm{~mm}$ 인 경우는 $f_{L}$ 과 $f_{H}$ 의 간격이 멀기 때문에, 통과 대역 중앙부의 리플 진폭이 커진다. $d=2.2 \mathrm{~mm}$ 인 경우는 $f_{L}$ 과 $f_{H}$ 의 간격 이 적절히 유지되어 정상적인 통과 대역이 형성된 다. $d=1.5 \mathrm{~mm}$ 인 경우는 $f_{L}$ 과 $f_{H}$ 가 더욱 근접하여 투과 특성이 나빠짐을 확인할 수 있다.

다음으로 L형 아이리스의 유무에 따른 주파수 응 답 특성을 비교하기 위하여 그림 $8(\mathrm{~b})$ 의 $S=9.61 \mathrm{~mm}$ 곡선과 그림 $9(\mathrm{~b})$ 의 $d=2.2 \mathrm{~mm}$ 곡선을 그림 10 에 동 시에 나타내었다.

두 경우, 모두 정상적인 통과 대역이 형성되었지 


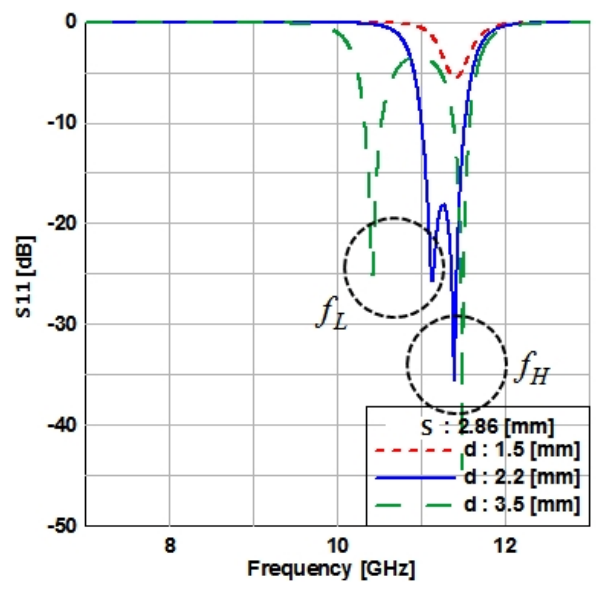

(a) 반사 계수 $\left(S_{11}\right)$

(a) Reflection coefficient $\left(S_{11}\right)$

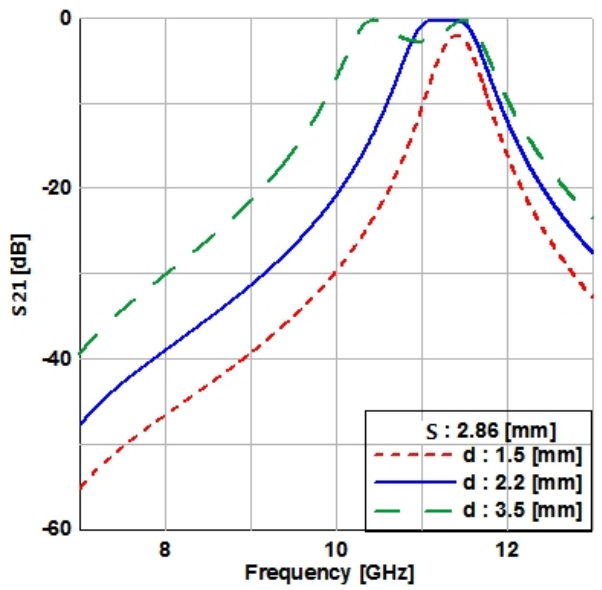

(b) 투과 계수 $\left(S_{21}\right)$

(b) Transmission coefficient $\left(S_{21}\right)$

그림 9. L형 아이리스 추가에 따른 주파수 응답 특성

Fig. 9. Frequency response using L-type iris.

만, L형 아이리스가 없는 경우에 공진 주파수는 10 $\mathrm{GHz}$ 이고, $\mathrm{L}$ 형 아이리스가 있는 경우에 공진 주파수 는 $11.2 \mathrm{GHz}$ 로 차이가 있다. 이를 보상해 주기 위하 여 리지가 장하된 소형 원형 개구의 치수를 기존의 $D=6.9, s=1.9, g=0.4$ 에서 $D=8, s=2.4, g=0.4$ 로 변경하 였다. 그 결과를 그림 11에 도시하였다.

그림 11을 통하여 두 가지 형태로 제작된 여파기 의 필터 특성이 거의 일치함을 확인할 수 있다. 그러 나 기존의 방식으로 설계된 여파기는 도파관의 에너 지 진행 방향으로의 길이가 동작 주파수인 $10 \mathrm{GHz}$ 에서 $\lambda / 4$ 인 약 $10 \mathrm{~mm}$ 에 해당한다면 본 연구에서 제 안한 방식으로 설계된 여파기는 도파관의 에너지 진

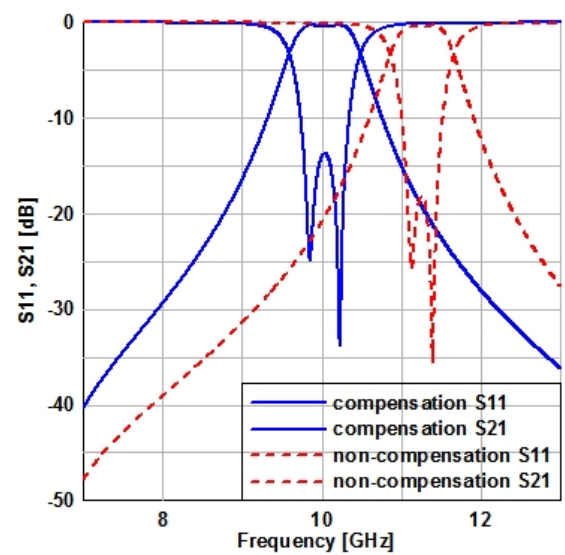

그림 10. 개구의 구조 변경에 따른 주파수 보상

Fig. 10. Frequency compensation by adjusting geometrical parameter of the aperture.

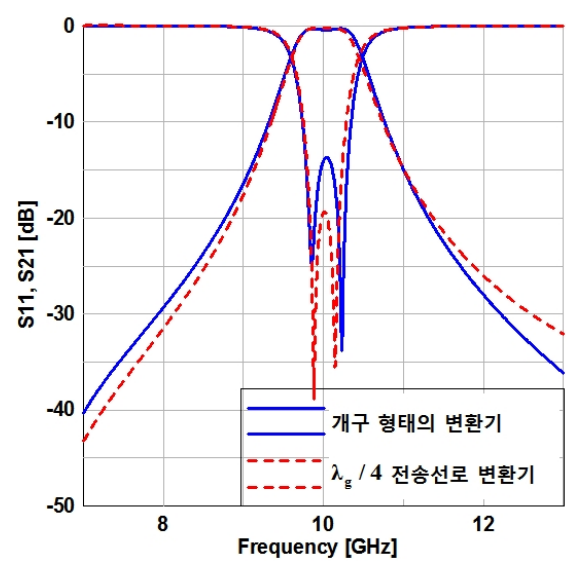

그림 11. 두 가지 형태의 impedance inverter를 사용하 여 구현한 여파기의 주파수 응답 특성 비교

Fig. 11. The comparison of frequency response for two types of band-pass filters by using different impedance inverters.

행 방향으로의 길이가 동작 주파수인 $10 \mathrm{GHz}$ 에서 $\lambda / 14$ 인 약 $3 \mathrm{~mm}$ 에 해당한다. 따라서 $\mathrm{L}$ 형 아이리스 를 사용하게 되면 기존의 여파기 설계 방식에 비하 여 주파수 응답 특성을 그대로 유지하면서 여파기의 물리적인 체적을 약 $70 \%$ 소형화할 수 있는 것이다.

\section{2-4 최종 제안된 여파기의 투과 특성 분석}

그림 12는 VNA(Vector network analyzer)를 이용하 여 최종 제작된 여파기의 투과 특성을 실험하기 위 한 시스템 구성을 도시한 것이다. 그림 13(a), (b)는 


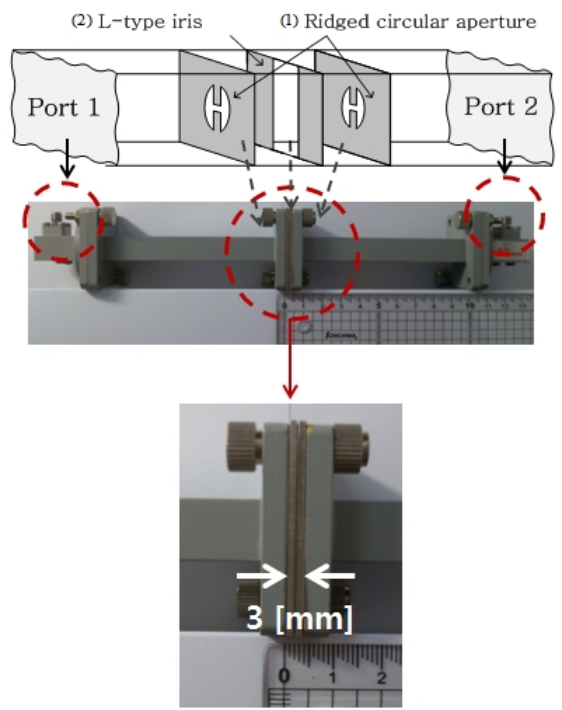

그림 12. 여파기의 투과 특성 측정을 위한 구성도

Fig. 12. Experimental setup for the measurement of transmission characteristics.

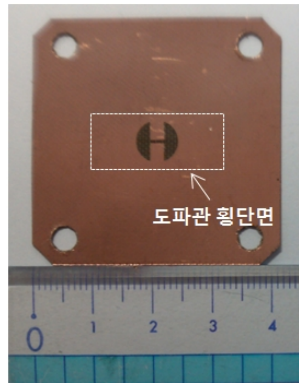

(a)

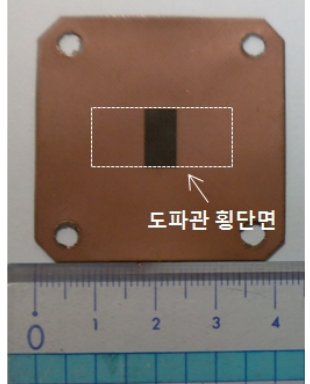

(b)

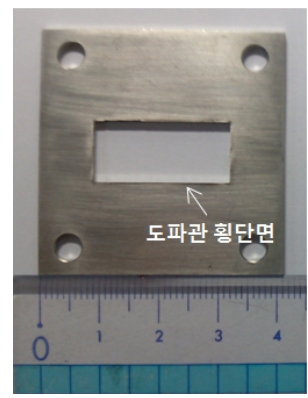

(c)

그림 13. $\mathrm{PCB}$ 상에 제작된 2가지 아이리스 및 스테인 리스 판재로 제작된 연결 구조

Fig. 13. Three irises fabricated on a PCB and a joint structure made of a stainless steel.

실험을 위해 제작된 2가지 아이리스 구조이며, 그림 $13(\mathrm{c})$ 은 각 아이리스 사이에 배치될 연결 구조(joint

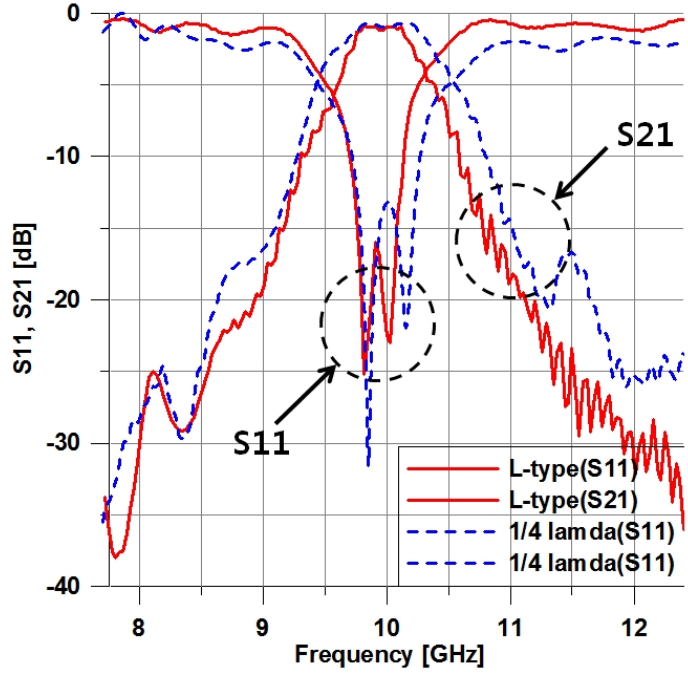

그림 14. 주파수 응답 특성 특정 결과

Fig. 14. Measured frequency response.

structure)이다.

그림 14는 그림 13에 도시된 구조물들을 그림 12 에 도시된 여파기 모형의 순서대로 도파관의 횡단면 에 배치한 후에 VNA를 이용하여 필터 특성을 나타 낸 것이다. 점선은 기존의 인버터 구조 $(\lambda / 4$ 변환기 $)$ 를 이용하여 구현한 여파기의 특성이며, 실선은 제 안한 인버터 구조(L형 아이리스)를 이용하여 구현한 여파기의 특성이다. 전자의 경우에 중심 주파수 10 $\mathrm{GHz}$ 에서 $500 \mathrm{MHz}$ 의 대역폭을 가지며, 후자의 경우 에 중심 주파수 $10 \mathrm{GHz}$ 에서 $400 \mathrm{MHz}$ 의 대역폭을 가진다. 이렇게 대역폭에 차이가 생기는 이유는 $\mathrm{L}$ 형 아이리스 상에 있는 슬릿 간격 $(d)$ 의 오차에 의한 것 이다. 그림 9 를 설명하면서 지적했듯이 슬릿 간격 $(d)$ 을 늘여서 $f_{L}$ 을 조정함으로써 이러한 대역폭을 조 절할 수 있다.

두 여파기의 물리적인 크기를 비교해 보면 $\lambda / 4$ 변 환기를 사용한 기존의 방식은 총 길이가 약 $9.61 \mathrm{~mm}$ 이고, $\mathrm{L}$ 형 아이리스를 사용한 경우에 총 길이가 약 $2.86 \mathrm{~mm}$ 이다. 이는 L형 아이리스를 도입하여 여파 기의 체적을 $70 \%$ 소형화한 것이다.

그림 14의 결과를 통하여 대역폭에 다소 차이는 있지만, 두 여파기의 필터 특성이 거의 일치하는 것 을 확인할 수 있다. 따라서 $\mathrm{L}$ 형 아이리스를 이용한 여파기는 기존의 $\lambda / 4$ 변환기를 이용한 여파기에 비 하여 동일한 성능을 유지하면서 여파기의 길이 방향 
크기를 약 $1 / 3$ 배로 줄일 수 있다.

\section{III. 결 론}

본 논문에서는 도파관의 단면에 아이리스 구조물 을 일정한 간격으로 배치하여 소형의 대역 통과 여 파기를 구현하는 연구를 수행하였다. 여파기의 구성 소자로는 리지가 장하된 소형 원형 개구 아이리스와 $\mathrm{L}$ 형 아이리스가 사용되었다. 리지가 장하된 소형 원 형 개구는 투과 공진 개구로서 도파관의 내부에 위 치하여 $\mathrm{L}, \mathrm{C}$ 공진 회로로 동작하게 된다. 따라서 여 파기 설계의 기본 공진기로 활용이 가능하다. $\mathrm{L}$ 형 아이리스는 도파관의 내부에 위치하여 L성분을 갖 는 것으로 알려져 있다. 본 연구에서는 투과 공진 개 구 사이에 $\mathrm{L}$ 형 아이리스를 위치시키는 구성을 통하 여 여파기를 소형화하는 방법을 제시하였다.

최종 제작된 여파기는 인버터 구조로서 $\mathrm{L}$ 형 아이 리스를 사용함으로써 기존에 $\lambda / 4$ 변환기를 인버터 구조로 사용한 여파기와 비교하여 동일한 성능을 유 지하면서 여파기 체적을 $1 / 3$ 배로 소형화하였다. 이 러한 소형화 기술은 위성 탑재용으로 여파기 기술 분야에 유용하게 활용될 수 있을 것으로 생각된다.

\section{부 록}

부록에서는 그림 15 와 그림 16 에 주어진 최종 제 안된 여파기를 구성하는 2 가지 아이리스 구조의 치 수를 나타내었다.

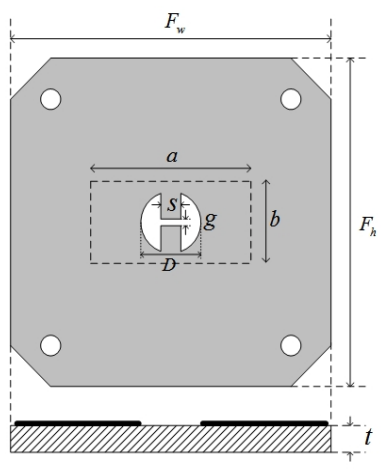

\begin{tabular}{|c|c|}
\hline 파라미터 & 치수 $(\mathrm{mm})$ \\
\hline$F_{\mathrm{w}}$ & 41.4 \\
\hline $\mathrm{F}_{\mathrm{h}}$ & 41.4 \\
\hline $\mathrm{a}$ & 22.86 \\
\hline $\mathrm{b}$ & 10.16 \\
\hline $\mathrm{D}$ & 8 \\
\hline $\mathrm{S}$ & 2.4 \\
\hline $\mathrm{g}$ & 0.4 \\
\hline $\mathrm{t}$ & 0.3 \\
\hline
\end{tabular}

Ridged circular aperture

그림 15. 리지가 장하된 원형 개구 아이리스의 치수

Fig. 15. Geometrical size of the ridged circular aperture iris.

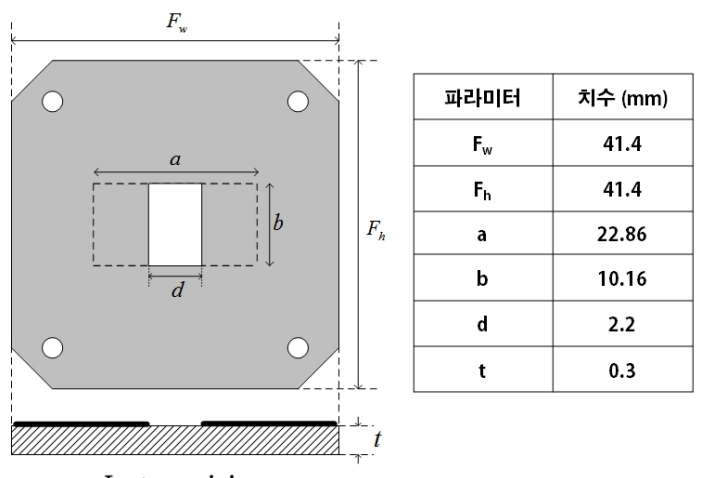

L-type iris

그림 16. L형 아이리스의 치수

Fig. 16. Geometrical size of the L-type iris.

\section{참 고 문 헌}

[1] M. Ohira, H. Deguchi, M. Tsuji, and H. Shigesawa, "Novel waveguide filters with multiple attenuation poles using frequency selective surfaces", 2005 IEEE MTT-S Int. Microwave Symp., Long Beach, CA, Jun. 2005.

[2] S. M. Amjadi, M. Soleimani, "Narrow band-pass waveguide filter using frequency selective surfaces loaded with surface mount capacitors", Electromagnetics in Advanced Applications, ICEAA, pp. 173-176, Sep. 2007.

[3] H. Bahrami, M. Hakkak, and A. Pirhadi, "Analysis and design of highly compact band-pass wave- guide filter utilizing complementary split ring resonators(CSRR)", Progress in Electromagnetics Research, vol. 80, pp. 107-122, 2008.

[4] N. Ortiz, J. D. Baena, M. B Beruete, F. CarciaGarcia, and M. Sorolla, "Complementary split ring resonator for compact waveguide filter design", Microwave and Optical Technology Letters, vol. 46, no. 1, Jul. 2005.

[5] 최진영, 고지환, 조영기, "CSRR 구조의 투과단면 적 계산", 한국전자파학회 전자파기술 하계학술 대회논문집, 12(1), p. 72, 2011년 7월.

[6] D. W. Pohl, W. Denk, and M. Lanz, "Optical stethoscopy: Image recording with resolution $\lambda / 20$ ", Appl. Phys. Lett., vol. 44, no. 7, pp. 651-653, Apr. 1984. 
[7] 1214M. Golosovsky, D. Davidov, "'Novel milli-meterwave near-field resistivity microscope", Appl. Phys. Lett., vol. 68, no. 11, pp. 1579-1581, Mar. 1996.

[8] R. F. Harrington, "Resonant behavior of a small aperture backed by a conducting body", IEEE Trans. Antennas Propagat., vol. 30, no. 2, pp. 205-212, Mar. 1982.

[9] X. Shi, L. Hesselink, and R. Thornton, "Ultrahigh light transmission through a $\mathrm{C}$-shaped nano-aperture", Opt. Lett., vol. 28, no. 15, pp. 1320-1322, Aug. 2003.

[10] M. J. Lockyear, A. P. Bins, J. R. Sambles, and C. R. Lawrence, "Enhanced microwave transmission through a single sub-wavelength aperture surrounded by concentric grooves", Journal of Optics A, vol. 7, pp. S152-S158, 2005.

[11] K. -W. Kim, J. W. Ko, J. E. Park, K. W. Kim, and Y. K. Cho, "Resonant transmission enhancement with a sub-wavelength aperture", Proceeding of IEEE Antennas and Propagation International Symposium 2007, pp. 1521-1524, Honolulu USA, Jun.

최 진 영

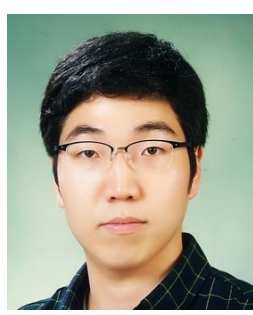

2010년 2월: 경북대학교 전자공학 부 (공학사)

2010년 3월 현재: 경북대학교 전 자전기컴퓨터 석사과정

[주 관심분야] 전자기 이론, 필터 설계
2007.

[12] J. Yeo, J. -W. Ko, J. -E. Park, and Y. -K. Cho, "FDTD analysis of resonant transmission in an electrically small circular aperture with a ridge", IEEE Antennas and Propagation Society International Symposium, pp. 1-4, Jul. 2008.

[13] 고지환, 조영기, 여준호, 이종익, "리지가 있는 소형 원형 개구의 공진 투과에 관한 연구", 한 국전자파학회논문지, 22(6), 2011년 6월.

[14] D. K. Cheng, Field and Wave Electromagnetics, 2nd Ed., pp. 559-562, Addison Wesley, 1989.

[15] H. Bahrami, M. Hakkak, and A. Pirhadi, "Using complementary split ring resonators(CSRR) to design bandpass waveguide filters", Proceeding of APMC2007, pp. 1-4, Dec. 2007.

[16] M. Ohira, H. Deguchi, M. Tsuji, and H. Shigesawa, "A new dual-behavior FSS resonator for waveguide filter with multiple attenuation poles", Proceeding of 35th European Microwave Conference, pp. 189-192, Paris, Oct. 2005.

김 병 문

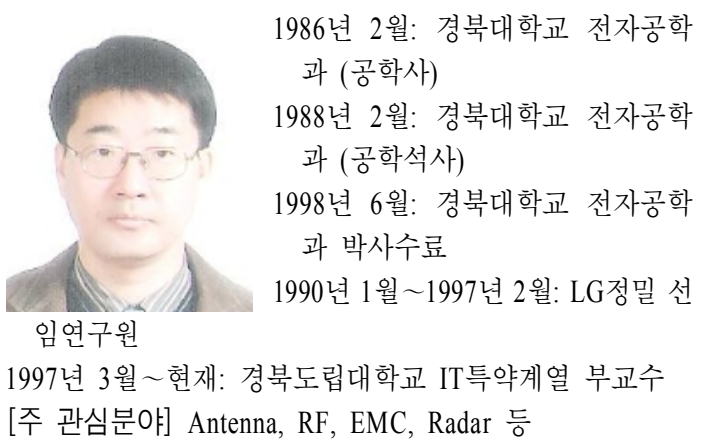




\section{조 영 기}

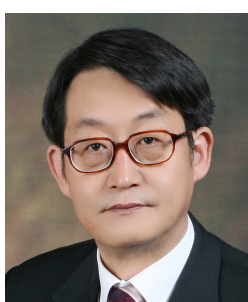

1978년: 서울대학교 전자공학과 (공 학사)

1981년: 한국과학기술원 전기 및 전 자공학과 (공학석사)

1998년: 한국과학기술원 전기 및 전 자공학과 (공학박사)

2008: 한국전자파학회 회장

1981년 현재: 경북대학교 IT대학 전자공학부 교수

[주 관심분야] 전자기 산란 및 복사, 주기 구조, 안테나 이 론 등 